\title{
Correction to: Cyclically stretched ACL fibroblasts emigrating from spheroids adapt their cytoskeleton and ligament-related expression profile
}

\author{
Clemens Gögele ${ }^{1,2} \cdot$ Christina Hoffmann $^{3}$. Jens Konrad ${ }^{3} \cdot$ Rudolf Merkel $^{3}$. Silke Schwarz ${ }^{1}$ Mersedeh Tohidnezhad ${ }^{4}$. \\ Bernd Hoffmann ${ }^{3}$. Gundula Gesine Schulze-Tanzil ${ }^{1}$
}

(c) The Author(s) 2021

\section{Correction to: Cell and Tissue Research https://doi.org/10.1007/s00441-021-03416-9}

The published online version contains an error of the figures not caused by the authors were the figures were mixed up in the original publication.

The original article has been corrected.

Open Access This article is licensed under a Creative Commons Attribution 4.0 International License, which permits use, sharing, adaptation, distribution and reproduction in any medium or format, as long as you give appropriate credit to the original author(s) and the source, provide a link to the Creative Commons licence, and indicate if changes were made. The images or other third party material in this article are included in the article's Creative Commons licence, unless indicated otherwise in a credit line to the material. If material is not included in the article's Creative Commons licence and your intended use is not permitted by statutory regulation or exceeds the permitted use, you will need to obtain permission directly from the copyright holder. To view a copy of this licence, visit http://creativecommons.org/licenses/by/4.0/.

Publisher's Note Springer Nature remains neutral with regard to jurisdictional claims in published maps and institutional affiliations.

The original article can be found online at https://doi.org/10.1007/ s00441-021-03416-9.

Gundula Gesine Schulze-Tanzil

gundula.schulze@pmu.ac.at;

gundula.schulze-tanzil@klinikum-nuernberg.de

Clemens Gögele

clemens.goegele@pmu.ac.at

Christina Hoffmann

c.hoffmann@fz-juelich.de

Jens Konrad

j.konrad@fz-juelich.de

Rudolf Merkel

r.merkel@fz-juelich.de

Silke Schwarz

schwarzbiggy@yahoo.de

Mersedeh Tohidnezhad

mtohidnezhad@ukaachen.de
Bernd Hoffmann

b.hoffmann@fz-juelich.de

1 Institute of Anatomy and Cell Biology, Paracelsus Medical University, Prof.-Ernst-Nathan Str. 1, 90419 Nuremberg and Salzburg, Nuremberg, Germany

2 Department of Biosciences, Paris Lodron University Salzburg, Hellbrunnerstr. 34, 5020 Salzburg, Austria

3 Institute of Biological Information Processing: IBI-2, Forschungszentrum Jülich, 52425 Jülich, Germany

4 Department of Anatomy and Cell Biology, RWTH Aachen University, Wendlingweg 2, 52074 Aachen, Germany 